\title{
Advances in Research of Dinoflagellates-lysing Bacteria and its Application Prospect in Aquaculture Ponds
}

\author{
Guoliang Wen ${ }^{1,2,3}$, Shasha $\mathrm{Li}^{1,2,3}$, Xiaojuan $\mathrm{Hu}^{1,2,3}$, Yu Xu ${ }^{1,2,3,{ }^{*}}$, Yucheng Cao ${ }^{1,2,3, *}$ \\ ${ }^{1}$ South China Sea Fisheries Research Institute, Chinese Academy of Fishery Sciences, Guangzhou, \\ Guangdong Province, China \\ ${ }^{2}$ Key Laboratory of South China Sea Fishery Research Exploitation \& Utilization, Ministry of Agriculture, \\ Guangzhou, Guangdong Province, China \\ ${ }^{3}$ Guangdong Provincial Key Laboratory of Fishery Ecology and Environment, Guangzhou, Guangdong \\ Province, China \\ *Corresponding author
}

Keywords: Dinoflagellates-Lysing Bacteria; Screening; Algae-Lysing Effect; Pond.

\begin{abstract}
The basic research on dinoflagellates-lysing bacteria and the development of its preparation technology have important scientific and application values in the fields of aquaculture and water environment. The paper systematically analyzes the isolation methods and algae-lysing mechanism of dinoflagellates-lysing bacteria, as well as its application prospect in ponds and urgent technical problems to be solved, aiming to provide scientific reference for further research and development of dinoflagellates-lysing bacteria preparations which can be used in ponds for environmental control.
\end{abstract}

\section{Introduction}

In recent years, pond culture develops rapidly in the coastal areas of China. But the emission of industrial sewage, the use of agricultural fertilizers and the increasing amount of domestic sewage lead to the frequent occurrence of red tide. Farmers use the polluted sea water as cultivation water, which causes the eutrophication of aquaculture ponds. The red tide algae reproduces quickly and become the dominant population. They inhibit the growth of beneficial algae, resulting in the decline of water productivity, and may harm to the safety of aquatic products. In addition, with the rapid development of aquaculture industry, intensive and semi-intensive pond culture are the main ways of aquaculture in China. [1] In intensive and semi-intensive culture ponds, the breeding density is high. If the water quality control is not reasonable, the water eutrophication will be aggravated, resulting in the outbreak of harmful dinoflagellate. A series of serious problems like diseases and the decline of product quality will occur. Since chemical and physical methods cannot solve the problem of dinoflagellate blooms in culture ponds effectively, researchers began to pay attention to the elimination of harmful dinoflagellate through dinoflagellate-lysing bacteria preparations. Algae-lysing bacteria form an important part of the aquatic ecosystem in the biological community. The application of algae-lysing bacteria can control the breeding of harmful algae, maintain the balance of population structure and biomass, maintain the long-term stability of aquaculture water environment, reduce the occurrence of disease and promote the healthy growth of culture species.

Therefore, this paper systematically analyzes the isolation methods and algae-lysing mechanisms of dinoflagellates-lysing bacteria, as well as its application prospect in ponds and urgent technical problems needs to be solved, aiming to provide scientific reference for further research and development of dinoflagellates-lysing bacteria preparations which can be used in ponds for environmental control. 


\section{Research Situation of Algae-lysing Bacteria}

Scholars have studied algae-lysing bacteria for decades. The earliest report about algae-lysing bacteria was in 1942. Geitler proposed that Polrangium, which is parasitic on Cladophora, could make algae die. [2] At present, most researches on algal bacteria are aimed at the prevention and control of red tides in open waters of the natural environment, such as lakes and coastal waters. The majority of researches focus on theoretical and experimental studies. [3] Rong-jun Shi collected surface seawater and sediment of Dapeng Bay at the red tide, and screened the marine bacteria which had algae-lysing effects on Scrippsiella trochoidea, Prorocentrum micans, Skeletonema costatum and phaeodactylum tricornutum. Shi used the 48 hole cell culture plate and liquid infection method to study the effects and function modes of algae-lysing bacteria. [4] Juan Liu collected water samples from Laizhou Bay, Jiaozhou Bay, Hongsha Port of Sanya, Hainan province and other water areas. By using the liquid infection method, two strains of marine bacteria HSB01 and HSB07, which had obvious inhibitory effects on Gymnodinium catenatum, were isolated. According to morphological observation, as well as molecular, physiological and biochemical identification, it was found that HSB01 was a genus of Staphylococcus, while HSB07 was a genus of Halomonas. [5] Although the freshwater dinoflagellate bloom is less common than marine dinoflagellate bloom, [6] it has happened for many times in China in recent years. [7] For example, in the East Lake of Wuhan, Hubei province, Peridiniopsis niei bloom periodically outbreaks. [8] In Manwan Reservoir of Yunnan Province, Dinoflagellate bloom often occurs in spring from 2003 to 2008. Through morphological studies, it was found that the species is a variant of Peridiniopsis penardii. [9] Chemical and physical methods cannot solve the problem of dinoflagellate blooms in culture ponds effectively. Through the application of dinoflagellate-lysing bacteria preparations, algae-lysing bacteria can eliminate the harmful effects of dinoflagellates on aquaculture products, optimize the ecological structure, and achieve the effect of ecological control. However, when developing algae-lysing bacteria agents, there are a number of urgent problems need to be solved, such as low fermentation yield, high cost, unstable microbial agents and biological safety issue.

At present, the research of Dinoflagellates-lysing bacteria is still in its initial stage; the research and development of Dinoflagellates-lysing bacteria preparations are blank. There are many kinds of bacteria which have Dinoflagellates-lysing effects. K.A. Seong and his colleges studied the algae-lysing effects of Vibrio parahaemolyticus on red tide dinoflagellates such as Scrippsiella trochoidea and Prorocentrum micans. [10] Y. Onishi and his group members studied the E8 and E9 allelopathy of Flavobacterium which can inhibit Alexandrium tamarense. [11] Dong Li screened a kind of bacteria which had strong ability of dissolving Alexandrium tamatense; the bacteria was identified as a member of Microbulbifer sp. [12] Guo-yong Liu identified algae-lysing bacteria H5, which could kill Peridiniopsis niei. The result showed that strain H5 belonged to Lysinibacillus fusiformis. [13] But at present, reports on the fermenting technology of different strains of Dinoflagellates-lysing bacteria and the application of bacteria in ponds are relatively rare.

\section{The Algae-lysing Modes of Algae-lysing bacteria}

There are two main modes of algae-lysing: direct algae lysing and indirect algae lysing. Direct algae lysing means, the bacteria directly contact with algal cells, then attack the host or even invade in algal cells. [14] Y. S. Kim isolated a strain of Bacillus named AB-4 in the South Korean coast. It can kill Chattonella marina, Akashiwo sanguinea, heterosigma akashiwo, Scrippsiella trochoidea and other red tide algae. [15] Hui Wang isolated 2 strains of algae-lysing bacteria, strain JZ1 and JZ2, from the sediments of the Jiaozhou Bay. The bacteria can kill skeletonema costatum effectively. Through the observation with fluorescence microscope, it was found that the membranous substances of skeletonema costatum became turbid after contacting with medium of strain JZ1. Then the cell membrane ruptured while the extracellular substances leaked. Thus, the effect of strain JZ1 on algae dissolution was direct algae lysing. [16] Rong-jun Shi collected surface seawater and sediment of Dapeng Bay at the red tide, and isolated one strain of marine bacteria which had algae-lysing effects 
on Prococentrum micans. The number of this strain is N10. Shi used liquid infection method to study the effects and function modes of this algae-lysing bacteria. The results showed that the strain N10 could deprive the activity of algal cells, then made them expand and deform. Then materials in the cell membrane gathered at one end, and the algae cells eventually died. The bacterium suspension and bacterium suspension after high temperature heating bacteria had no algae-lysing effects on Prorocentrum micans. The results showed that the algae lysing modes of strain N10 was direct algae lysing. [17]

Indirect algae-lysing means, the bacteria can inhibit the growth of algae or kill algae through secreting some metabolic products or nutritional competition. [18] J. D. Kim and his colleagues isolated and identified a new strain of Pseudoalteromonas, AFMB-08041, in Masan Bay of South Korea. The bacteria can secrete glucosidase which has specific effects on Prorocentrum. At the concentration of $2.5 \times 104 \mathrm{CFU} / \mathrm{mL}$, it can kill more than $90 \%$ of the algae cells of Prorocentrum in five days. [19] Hai-yan Pei and other scholars studied the algae lysing effect of the isolated bacterial strain. It was found that after filtrating the bacteria solution with $0.22 \mu \mathrm{m}$ filter membrane, it still had good algae-lysing effects, indicating that the bacteria did not need to contact with algae cells directly, and it killed algae through secreting a kind of non-protein substance. [48] Wen-juan Li found that, the two strains of algae lysing bacteria isolated from Three Gorges Reservoir area indirectly kill algae through releasing extracellular substances. The extracellular algae lysing substances belonged to non protein substances with thermal stability. The two strains of bacteria belonged to the microbacterium and Chryseobacterium respectively. [49]

\section{Application Prospect}

The change of microalgae in aquaculture ponds affects the stability of water environment and the healthy growth of culture species, and then affects the efficiency of aquaculture. Bacteria is an important component in aquatic ecosystems. It exerts important influence over water purification and bioremediation in ponds. It can provide plankton with nitrate nitrogen and ammonia nitrogen through nitrification and ammoniation; it can also inhibit the growth of algal cells through direct or indirect approaches, or even kill the cells. The application of dinoflagellate-lysing bacteria preparations is a safe and efficient way to control water quality; it can build good algae communities, inhibit the growth of harmful algae and bacteria, optimize water environment, control the occurrence of disease, and further improve the economic and ecological benefits of aquaculture production.

Apart from the algae-lysing effects, researchers should put more focus on the methods and safety of introduction when using algae-lysing bacteria preparations in aquaculture ponds. The aquaculture ecosystem is very complex; there is an equilibrium relationship between microorganisms. [21] The ideal goal of using dinoflagellate algae-lysing bacteria preparation in aquaculture ponds is, after introducing a certain amount of algae-lysing bacteria into the water body, a new dynamic equilibrium can be established to improve the water quality, inhibit the growth of pathogenic bacteria, and help breeding species to grow healthfully. Bacterial method is a new strategy to control algae bloom in aquaculture ponds. It has extensive research prospects though many technical problems remain to be solved.

According to the actual situations of aquaculture ponds, the author holds that there are three methods of application when using algae-lysing preparations. First, a small amount of algae-lysing preparation is used for several times to prevent and control the algae blooms in culture ponds. Hong-hui Huang and other researchers put forward that although the early stage of culture is relatively stable, different water quality management measures used in the early stage have significant impacts on the breeding effects of the middle and late stages. [22] Second, a large amount of algae-lysing preparation is used at one time in the outbreak period of bloom. Third, a small number of algae-lysing preparation is used for several times during the outbreak period of water bloom. The concentration and amount of bacteria preparations, as well as the using method and frequency, should be further studied from the perspectives of seasons and breeding species. 


\section{Acknowledgement}

Fund Project: This study is supported by the Foundation for Basic Scientific Research Projects of Chinese Academy of Fishery Sciences (Project No.: 2017HY-ZD0501) and the Fund for Special Projects in the Program of Industrial Technologies for Modern Agriculture (Shrimps and Crabs) (Project No.: CARS-48). It is also supported by the Foundation for Science and Technology Projects of Guangdong Province (Project No.: 2014B040404056, 2017A040405001), the Fund for Special Projects in the Fishing Port Construction and Industrial Development Program of Guangdong Province (Project No.: A201701B06) and the Foundation for Basic Scientific Research Projects of State-level Scientific Research Institutions of the South China Sea Fisheries Research Institute (Project No.: 2016TS03). I would like to express my gratitude to all those who helped me during the writing of this thesis. They are Wu-jie Xu, Hao-chang Su, Xiao-shuai Huang, Zhuo-jia Li, Zhi-wei Sun, Min-na Hong and Chuang-wen Xu.

\section{References}

[1] Y.C. Cao, Z.J. Li, Y.Y. Yang, et al., Research progress in the application of planktonic microalgae ecological regulation technology in shrimp culture, J. South China Fisheries Science. 3 (2007).

[2] Y.J. Zhao, Y.D. Liu, the basis of preventing and controlling harmful algae and microbes: a study on the relationship between bacteria and algae, J. Acta Hydrobiologica Sinica. 20 (1996).

[3] L.H. Wang, Y.C. Cao, Z.J. Li, et al. The algal control function of algae-lysing bacteria and its application prospect in shrimp culture ponds, J. South China Fisheries Science. 8 (2012).

[4] R.J. Shi, Study on the screening of marine algae lysing bacteria and algae lysing characteristics, Shanghai Ocean University, Shanghai, 2012.

[5] J. Liu, Screening of dinoflagellate algae and the inhibition of its secondary metabolites, Nanjing Agricultural University, Nanjing, 2013.

[6] S. Rodriguez, A. Coute, L. Tenhage, et a1., Peridiniopsis durandi sp. nova (Dinophyta), a new freshwater dinoflagellate causing red tides, J. Archiv fur Hydrobiologie (Supplement). 130 (1999).

[7] H.B. Tang, G.X. Liu, Z.Y. Hu, Research on the water bloom of dinoflagellate in the Gaolan River of Three Gorges Reservoir Region, J. Acta Hydrobiologica Sinica. 30 (2006).

[8] G.X. Liu, G.F. Pei, Z.Y. Hu, Peridiniopsis niei sp. Nov.(Dinophyceae), a new species of freshwater red tide dinoflagellates from China, J. Nova Hedwigia. 87 (2008).

[9] Q. Zhang, G. Liu, Z. Hu, Morphological Differences and Molecular Phylogeny of Freshwater Blooming Species, Peridiniopsis spp. (Dinophyceae) From China, J. European. Journal of Protistology. 47 (2011).

[10] K.A. Seong, H.J. Jeong, Interactions Between the Pathogenic Bacterium Vibrio parahaemolyticus and Red-tide Dinoflagellates, J. Ocean Science Journal. 46(2011).

[11] Y. Onishi, Y. Mohri, A. Tuji, et al., The seagrass Zostera marina harbors growth-inhibiting bacteria against the toxic dinoflagellate Alexandrium tamarense, J. Fisheries Science. 80(2014).

[12] D. Li, X.L. An, L.J. Han, et al., Isolation and identification of algicidal bacteria BS03 and its influences on the growth of Alexandrium tamarense, J. Acta Scientiae Circumstantiae. 33 (2013).

[13] G.Y. Liu, Y.P. Hu, X.D. Shi, et al., Isolation, identification and characterization of algae-lysing bacteria H5, J. Journal of Anhui Agricultural Sciences. 40 (2012).

[14] Y. K. Lee, C.Y. Ahn, H.S. Kim, et al., Cyanobactericidal effect of Rhodococcus sp. isolated from eutrophic lake on Microcystis sp, J. Biotechnology Letters. 32 (2010).

[15] Y.S. Kim, D.S. Lee, S.Y. Jeong, et al., Isolation and characterization of a marine algicidal bacterium against the harmful raphidophyceae Chattonella marina, J. Journal of Microbiology (Seoul, 
Korea). 47(2009).

[16] 2011. H. Wang, Inhibitory effect of algal bacteria on blooms and red tide algae, Nanjing Agricultural University, Nanjing, 2011.

[17] R.J. Shi, H.H. Huang, Z.H. Qi, et al., The algae lysing effect of a strain of algal bacteria on the marine Prorocentrum, J. Acta Ecologica Sinica. 32 (2012).

[18] G.J. Doucette, E.R. McGovern, J.A. Babinchak, Algicidal bacteria active against Gymnodinium breve (Dinophyceae). I. Bacterial isolation and characterization of killing activity, J. Journal of Phycology. 35(1999).

[19] J.D. Kim, J.Y. Kim, J.K. Park, et al. Selective control of the Prorocentrum minimum harmful algal blooms by a novel algal-lytic bacterium Pseudoalteromonas haloplanktis AFMB-008041. J. Marine Biotechnology (New York, N.Y.). 11(2009).

[20] T.L. Zheng, Y. Tian, J.Q. Su, et al., Study on the ecological relationship between marine red tide organisms and several bacteria in Xiamen sea area, J. Acta Ecologica Sinica. 22 (2002).

[21] Z.J. Li, Y.W. Li, Y.C. Cao, et al., Relationship between planktonic microalgae, bacteria and water quality in shrimp culture environment, J. Journal of Guangdong Ocean University. 29 (2009).

[22] H.H. Huang, Q. Lin, Z.X. Guo, et al., The influence of beneficial microorganism on the number and dynamic change of bacteria in seawater shrimp culture, J. South China Fisheries Science. 3 (2007). 